\title{
A moth-eaten radius
}

\section{Faisal Shehzaad Khan, ${ }^{1}$ Adrian B Walker, ${ }^{2}$ Joseph M Pappachan ${ }^{2}$}

${ }^{1}$ UHNS, Stoke on Trent, UK ${ }^{2}$ Department of Endocrinology, Diabetes \& Metabolism, UHNS, Stoke on Trent, UK

\section{Correspondence to} Dr Faisal Shehzaad Khan, shehzaad_khan@hotmail.com

\section{DESCRIPTION}

A 67-year-old right-handed man, with known renal cell carcinoma (RCC), presented to the hospital with a painful and swollen right wrist joint and severe hypercalcaemia (albumin-corrected serum calcium level of $3.6 \mathrm{mmol} / \mathrm{L}$ ) with low parathyroid hormone levels $(0.6 \mathrm{pmol} / \mathrm{L})$. He was known to have RCC (histologically proven clear cell subtype) with metastasis to the lung (disease stage IV; T3aN1M1). Physical examination revealed a swollen and deformed right wrist joint that was tender to palpation.

A plain radiograph showed a large soft tissue swelling of the right wrist and a $3 \mathrm{~cm}$ lytic lesion in the radius (figure 1) with permeative bony destruction and a pathological fracture of the distal epiphysis. There was dislocation of the wrist with permeative bone loss of the distal ulnar metaphysis and epiphysis (figure 2). MRI of the wrist showed

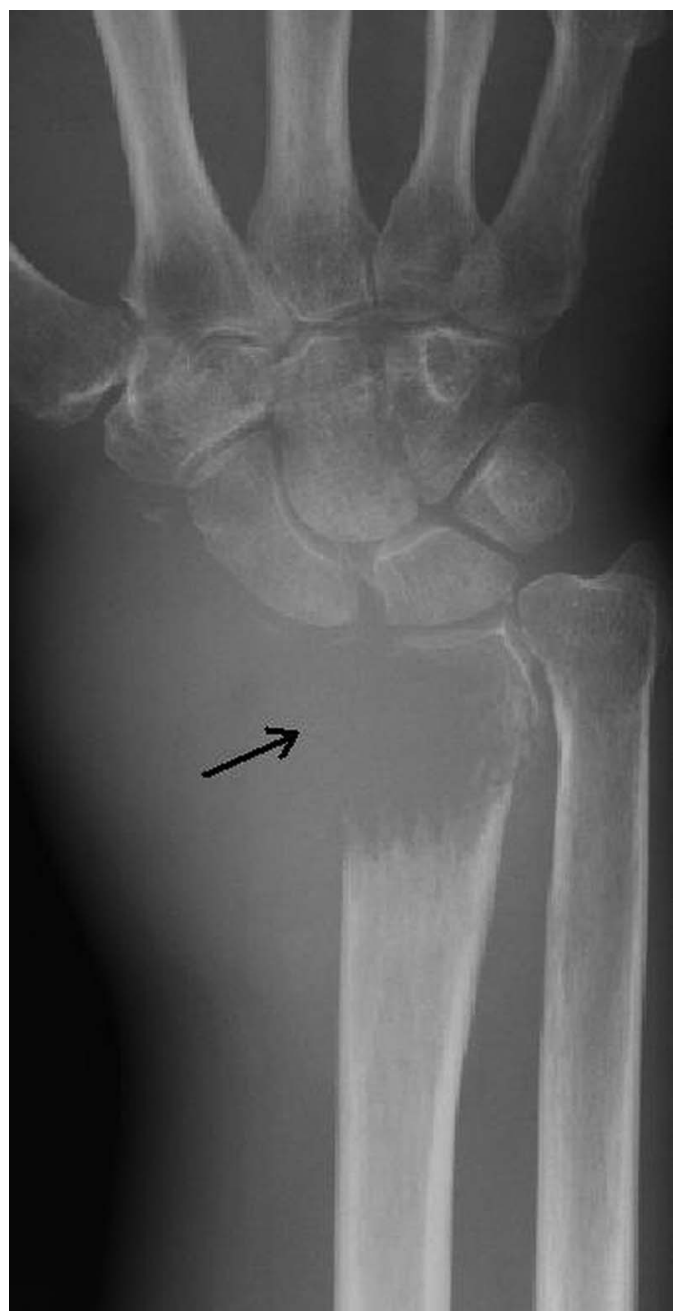

Figure 1 An anteroposterior radiograph of the right wrist showing osteolysis of the radius (black arrow). destruction of the distal right radial epiphysis with a large fleshy tumour measuring $6.1 \times 5.5 \times 5.8 \mathrm{~cm}$ (figure 3 ) with involvement of the skin and subcutaneous tissues. MRI showed prominent flow voids in the tumour consistent with RCC metastasis.

Administration of intravenous fluids and palmidronate brought the hypercalcaemia under control and his wrist was immobilised in a plaster-of-Paris cast. The patient declined external fixation of the joint for definitive treatment and chose palliativecare with opioid analgesics.

RCC accounts for $3 \%$ of all adult cancers and about $90 \%$ of renal neoplasms. ${ }^{1}$ RCC metastasises predominantly to the axial skeleton ${ }^{2}$ and metastasis to the radius is unusual. There are two prognostic models for RCC, namely, the Memorial Sloan-Kettering Cancer Center (MSKCC) model and the Heng model. ${ }^{3}$ In the MSKCC model,

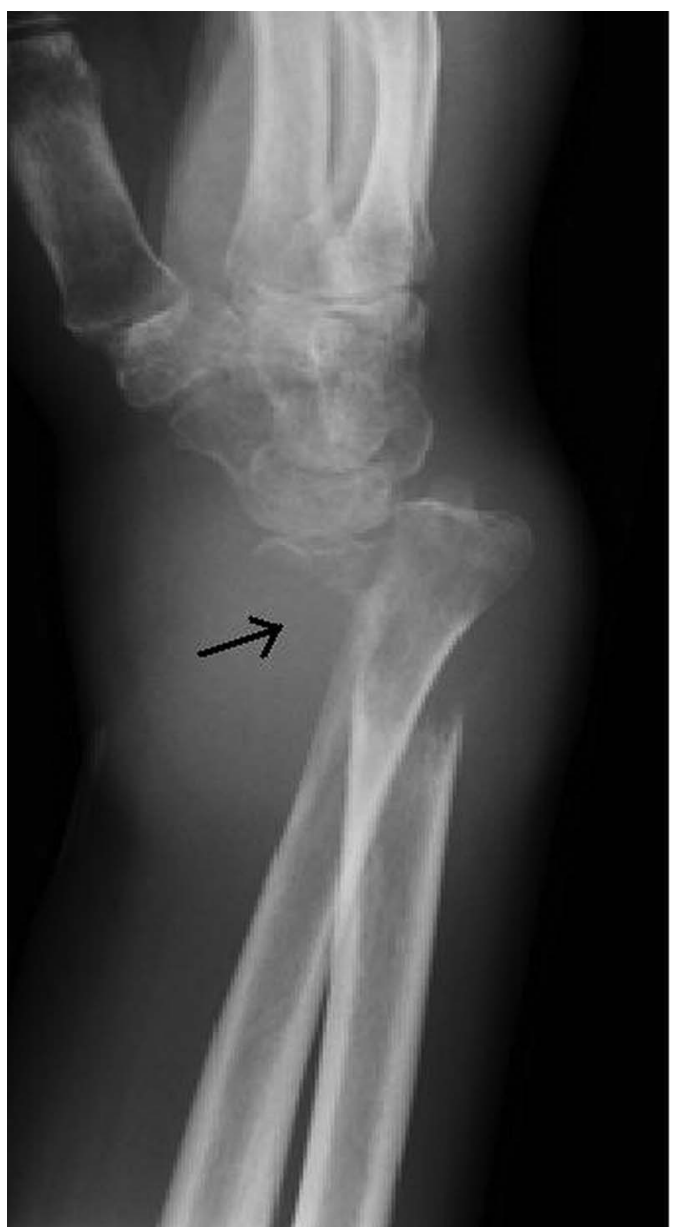

Figure 2 A lateral radiograph of the right wrist showing fracture and dislocation of the forearm bones and wrist (black arrow). 


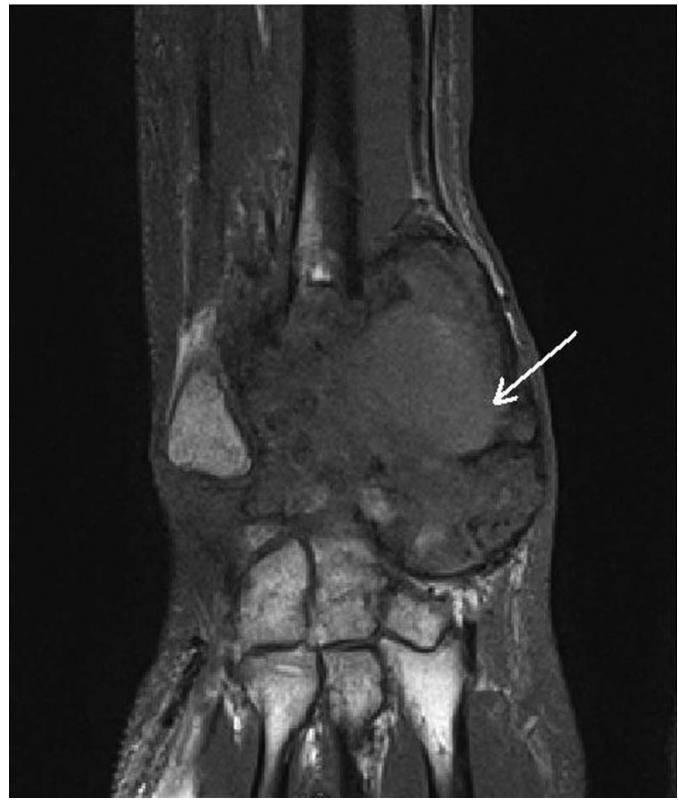

Figure 3 MRI showing the fleshy metastatic tumour (white arrow).

hypercalcaemia was found to be associated with a poor prognosis and an advanced stage of the disease.

\section{Learning points}

- Renal cell carcinoma (RCC) accounts for about 3\% of adult malignancies and about $90 \%$ of neoplasms of the kidney. ${ }^{1}$

- RCC metastasises predominantly to the axial skeleton. ${ }^{2}$

- The presence of hypercalcaemia indicates advanced disease and a poor prognosis in RCC. ${ }^{3}$

Contributors FSK, ABW and JMP have all contributed in the care of the patient, writing of the case report and literature search.

Competing interests None.

Patient consent Obtained.

Provenance and peer review Not commissioned; externally peer reviewed.

\section{REFERENCES}

1 Flanigan RC, Campbell SC, Clark Jl, et al. Metastatic renal cell carcinoma. Curr Treat Options Oncol 2003;4:385-90.

2 Zekri J, Ahmed N, Coleman RE, et al. The skeletal metastatic complications of renal cell carcinoma. Int J Oncol 2001;19:379-82.

3 Kwon WA, Cho IC, Yu A, et al. Validation of the MSKCC and Heng Risk Criteria Models for predicting survival in patients with metastatic renal cell carcinoma treated with sunitinib. Ann Surg Oncol 2013;20:4397-404.

Copyright 2014 BMJ Publishing Group. All rights reserved. For permission to reuse any of this content visit

http://group.bmj.com/group/rights-licensing/permissions.

BMJ Case Report Fellows may re-use this article for personal use and teaching without any further permission.

Become a Fellow of BMJ Case Reports today and you can:

- Submit as many cases as you like

- Enjoy fast sympathetic peer review and rapid publication of accepted articles

- Access all the published articles

- Re-use any of the published material for personal use and teaching without further permission

For information on Institutional Fellowships contact consortiasales@bmjgroup.com

Visit casereports.bmj.com for more articles like this and to become a Fellow 